\title{
Testing of Technical Indicators of Accumulators by Means of Complex Computer Model of EV
}

\author{
Jurijs Fedotovs (Institute of Industrial Electronics and Electrical Engineering, \\ Riga Technical University, Riga, Latvia), \\ Inna Bunina (Institute of Industrial Electronics and Electrical Engineering, Riga Technical University, Riga, Latvia), \\ Anastasia Zhiravetska* (Institute of Industrial Electronics and Electrical Engineering, \\ Riga Technical University, Riga, Latvia), \\ Svetlava Andrianova (Institute of Industrial Electronics and Electrical Engineering, \\ Riga Technical University, Riga, Latvia)
}

\begin{abstract}
The accumulators utilized in electric transport differ from those of other applications. Their main features are high capacity, minimum size and weight, and reasonable price. There is extensive research worldwide to improve the battery technology. The aim of the research is to create a mathematical model of an electric vehicle that can capture the vehicle speed curve as a data input to generate the consumed and recovered battery current, which can allow the battery parameters to be analysed and conclude whether the vehicle can perform the trip around the city route with the selected battery parameters. This model serves as a tool to simplify and speed up the necessary calculations and to examine individual sections of the route and their impact on the battery. To complete this task, a simplified electric transport mathematical model gives an opportunity to check if the selected battery can be used in the electrical public transport of the city. The input parameters of the model are the parameters of electrical transport. Simulation of the most popular types of batteries has been performed for two routes of buses in Jelgava in order to determine whether the chosen batteries can provide the necessary bus movement. The mathematical model has been developed in the MATLAB/Simulink software. A GPS mobile application SpeedTracker has been used for data logging.
\end{abstract}

Keywords - Batteries; Electric vehicle; Electromechanical systems; Motor drives; Vehicle.

\section{INTRODUCTION}

Among the existing battery technologies applicable to electrical vehicles, the lithium-ion batteries are the most promising ones. Compared with other types of batteries such as lead-acid batteries, nickel-cadmium (Ni-Cd) batteries and nickel-metal hydride (Ni-MH) batteries, lithium-ion batteries are superior in terms of high energy efficiency and power density, which allow them to be designed lighter and smaller in weight and size, respectively. Different types of the lithium-ion batteries have different energy capacity, which is one of the key factors to determine suitability and potentiality in applications of electrical buses. Moreover, other advantages of lithium-ion batteries include a wide temperature range of operation, rapid charge capability, no memory effects, relatively long cycle life and low self-discharge rate [1]-[4]. Lithium-ion battery cells have been developed to utilize fewer materials or other materials with much higher specific capacity. These types of lithium-ion batteries offer different advantages, such as high-rate capability, low cost, high thermal stability, long cycle life, and/or high capacity [5], [7]-[15]. Although the lithium-ion batteries have relatively low rated voltages, they are less expensive and more reliable and durable in electrical buses [16]-[19]. All this large variety of accumulator types, parameters, characteristics and reaction for operational conditions often causes difficulties and questions while selection for a particular case of application [20], [24], [25].

The aim of the research is to develop a mathematical model for the urban electric vehicle and to test it on the selected city route in order to examine the performance of various battery types on these routes under different climate conditions (humidity, temperature, etc.) to find the best type of battery to meet the urban transport needs [15]-[18].

In order to create a mathematical model and to run simulation for electric transport, the following system components are needed: the power supply or in this case a battery the chemical base of which will be changed during the simulation; frequency converter; electric motor; bus technical parameters; route consumption and recuperation curves, or route acceleration and braking curves.

The supply sources were modelled on the basis of source equivalent schemes composed of different elements such as capacitors, resistors, diodes and voltage sources, which are easy to model in such software as LTSpice or others. The basics of this model are the algebraic or differential equations that suit MatLab/Simulink environment. Such data as speed and mass of the vehicle were applied to the calculation of the force required for the movement, as well as such elements as inverters and $\mathrm{dc} / \mathrm{dc}$ converters were taken into account in the model in the way of increased efficiency factors in the equations. The data of the vehicle mechanics for the modelling of the behaviour were taken from the running at Jelgava bus park vehicles - Ambassador.

\footnotetext{
* Correspongong author.

E-mail: Anastasija.ziravecka@rtu.lv
} 
The input of the proposed mathematical model was supplied with a speed curve changing in time taken during the experiment. This speed curve described the dynamics of the vehicle on the road - acceleration and braking processes. The required traction force was calculated in accordance with the speed of the vehicle that was indicated with the feedback in the system. The parameters of the vehicle - bus in our case allowed for the calculations of electric drive power [21]-[24].

\section{PREPARATION OF THE INITIAL DATA FOR MODELLING}

Depending on the construction of the electric vehicle (battery or hybrid), part or all of the built-in battery capacity ensures vehicle movement and operation. The information discussed below dealt purely with electric vehicles running from a builtin battery. Like conventional transport, the power drive chain must be able to operate under all driving conditions. In addition, the electric vehicle must provide regenerative braking to use the kinetic energy of the vehicle to charge the batteries. This model was developed as a tool that could simplify and speed up the necessary calculations for battery parameter selection in electric transport based on manufacturers' technical data.

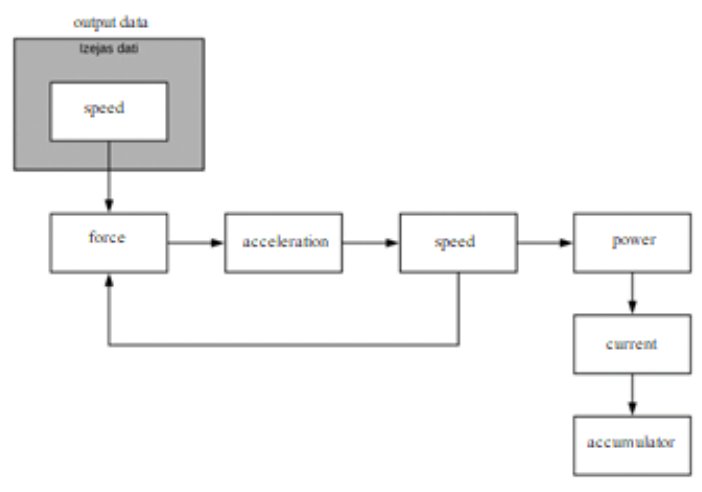

Fig. 1. The proposed algorithm of the model operation.

The input of the proposed mathematical model was the time dependence of the speed (Fig. 1) that was experimentally taken. This speed dependence demonstrated the dynamics of the vehicle on the route - acceleration and braking. Speed gave an opportunity to calculate the tracking force necessary to achieve the experimentally fixed speed. This process was characterised by means of a tracking model. The feedback signal was the speed calculated from the tracking force. With the given parameters of the vehicle, the electric power was calculated. The current of the accumulator was calculated by means of frequency converter power voltage of the converter, assuming it as constant.

Modelling required obtaining the speed curves for the vehicle routes (Fig. 2). Therefore, it was necessary to use the smart application SpeedTracker. The curve was taken according to GPS data with a $2 \mathrm{sec}$ step. Two routes of a city of Latvia Jelgava - were selected - route No. 2 and No. 5. Route No. 2 is the longest route in the city $17.5 \mathrm{~km}$; it contains 33 bus stops and takes 40 minutes. Route No. 5 relates to an average load of public transport in Jelgava. The length of the route is $13 \mathrm{~km}$; it goes through the centre of the city at the same time running to a close suburb; it includes 24 stops and lasts 34 minutes (Fig. 3).

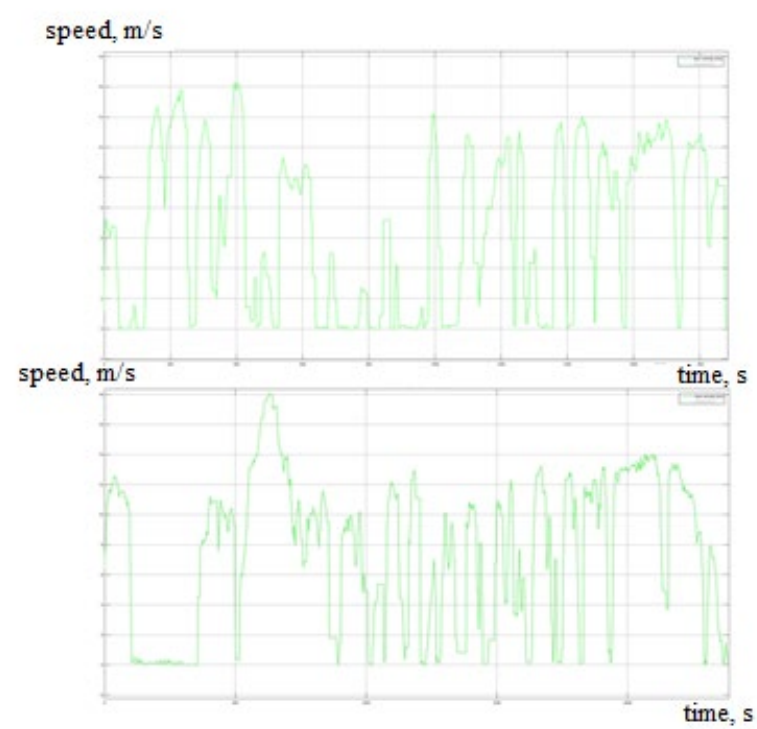

Fig. 2. Speed time diagrams of routes 5 and 2 correspondently applied to modelling.
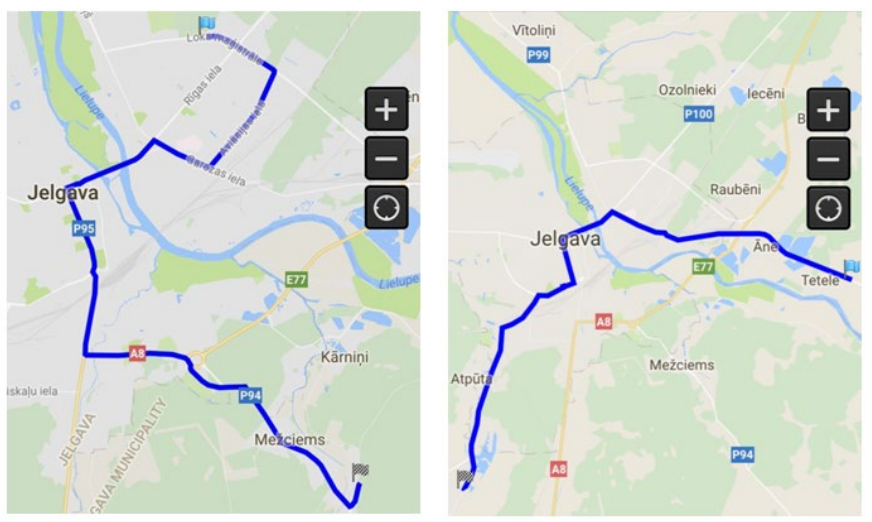

Fig. 3. Routes 5 and 2 in the map. Figures from SpeedTracker application.

\section{MODELLING THE RESULTS}

The data of the vehicle and other factors and parameters were obtained from the technical documentation of Jelgava vehicle park and sources of technical information. Parameters of Nissan Leaf lithium-ion accumulator were taken as a basis for accumulators $-24 \mathrm{kWh}-$ that can run $160 \mathrm{~km} \mathrm{[25],} \mathrm{[26].} \mathrm{The}$ mathematical model was used for the calculation of the simulation (Fig. 4).

Two parameters were compared in order to prove the accuracy of the model: the model could follow the speed diagram in accordance with the pre-set parameters and the calculated distance of the route matched that of the real route (Fig. 5).

Figure 6 shows the curves of the currents, the negative peaks of which corresponded to the regime of the regeneration. The peaks can achieve the level of $600 \mathrm{~A}$ at the acceleration of the vehicle. The current diagrams were generated in accordance with the speed diagrams and were similar for different types of accumulators during the modelling time. 


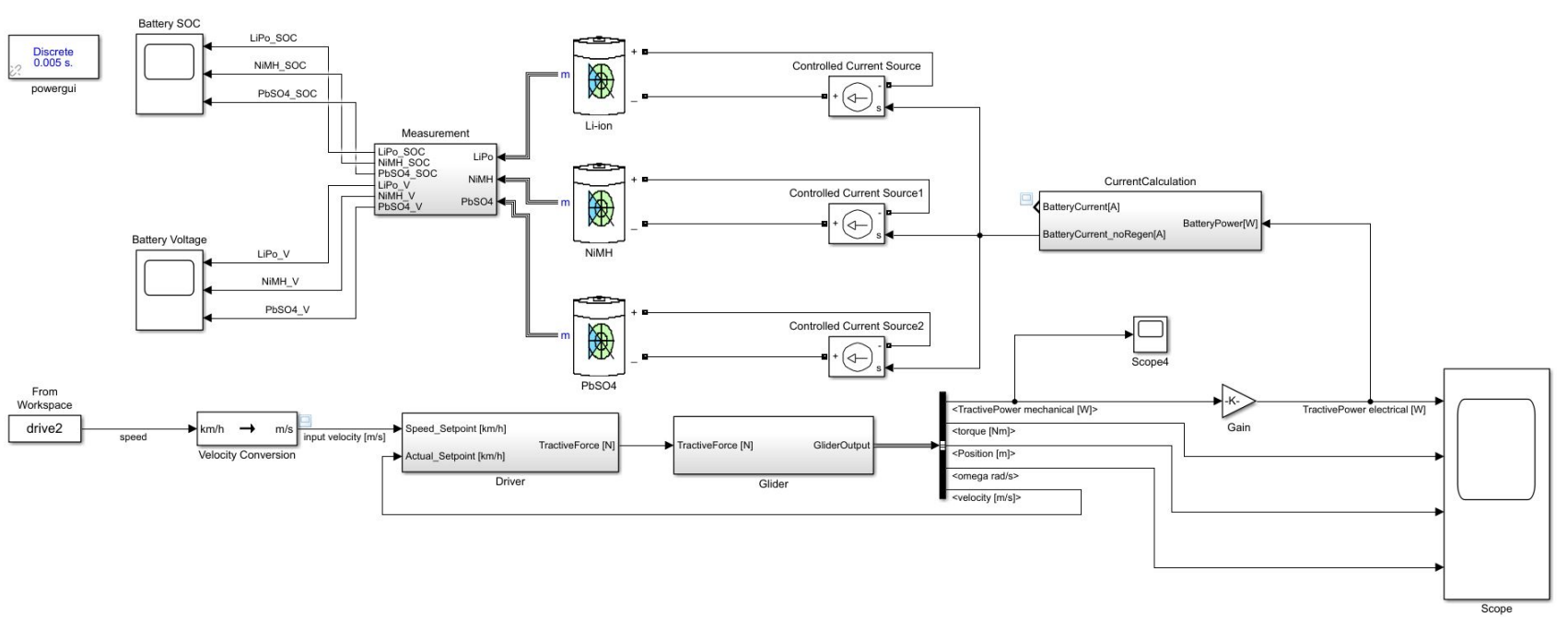

Fig. 4. The general view of the developed MatLab model.

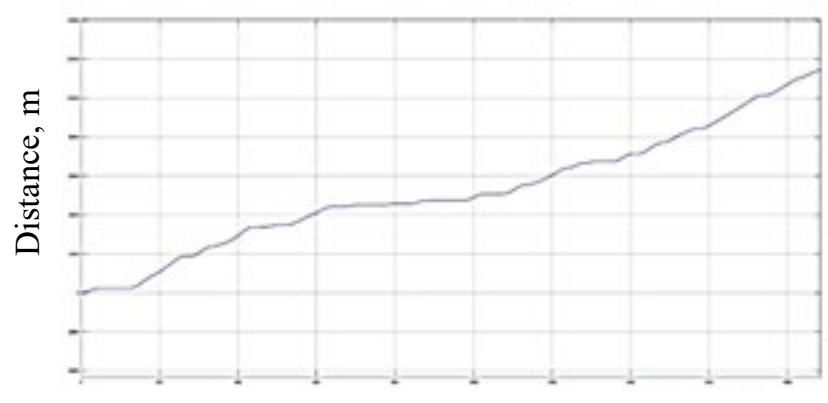

Time, $s$

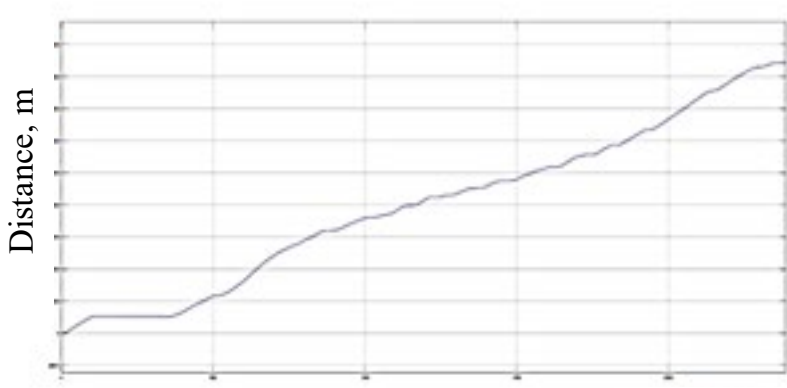

Time, $\mathrm{s}$

Fig. 5. Distance for routes No. 5 and No. 2 calculated in the model.

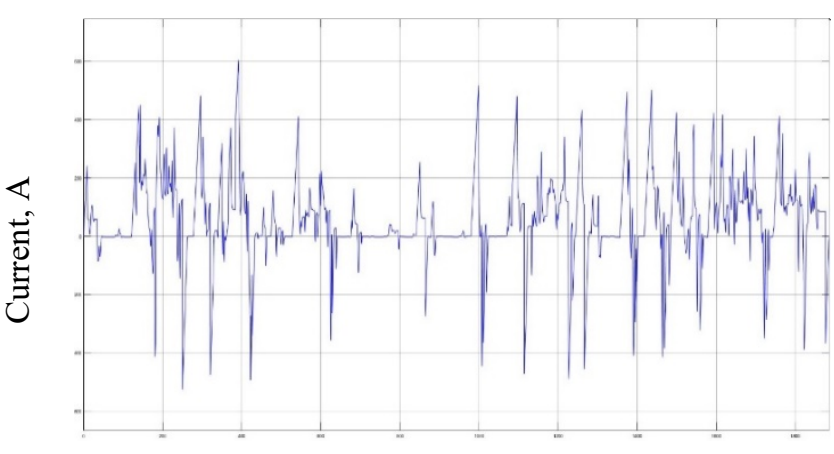

Time, s

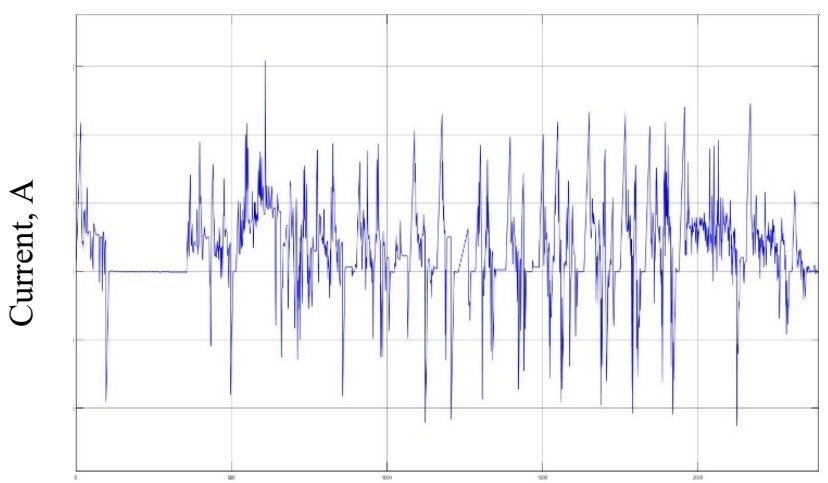

Time, s

Fig. 6. Current of the accumulators calculated during modelling for both routes.

\section{A. Modelling the Charging Level for Different Types of Accumulators}

The accumulators of different types were investigated under the same route conditions (Fig. 3). The basic assumption was that all of them started their work being $100 \%$ charged. Table I summarises the modelling results.
Lower charging on route No. 2 is related not only to the length of the route, but also to that fact that the bus runs out of the city where the distances between the stops are longer.

For the comparison and analysis of the results, modelling was also run without considering the regeneration process simulation of the regime with regeneration absence. 

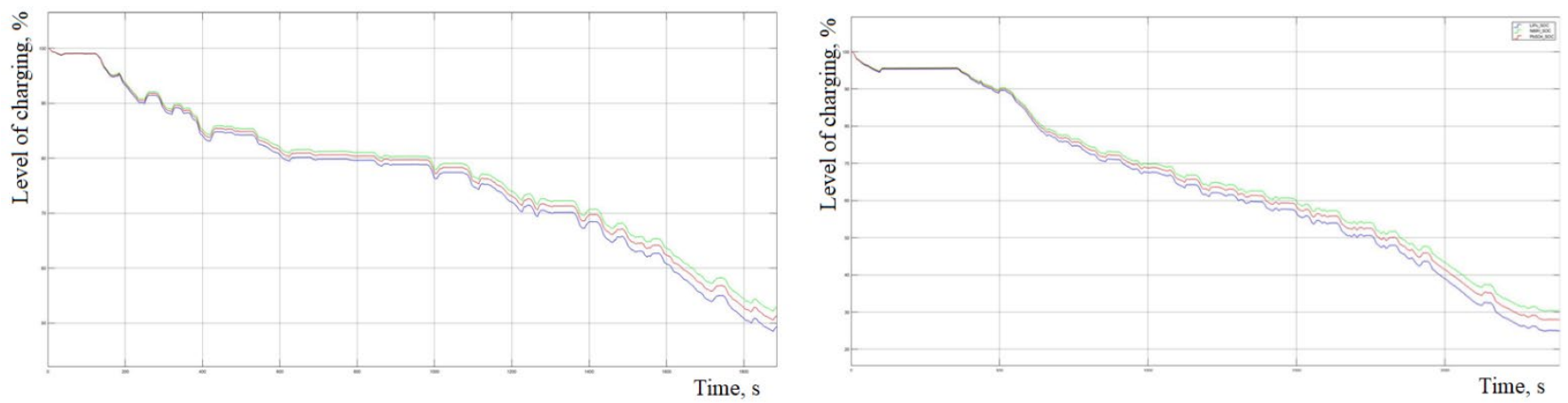

Fig. 7. Discharge levels of different accumulators of routes No. 5 and No. 2. Green - nickel-metal hydride, red - lead acids; blue - lithium-ion.
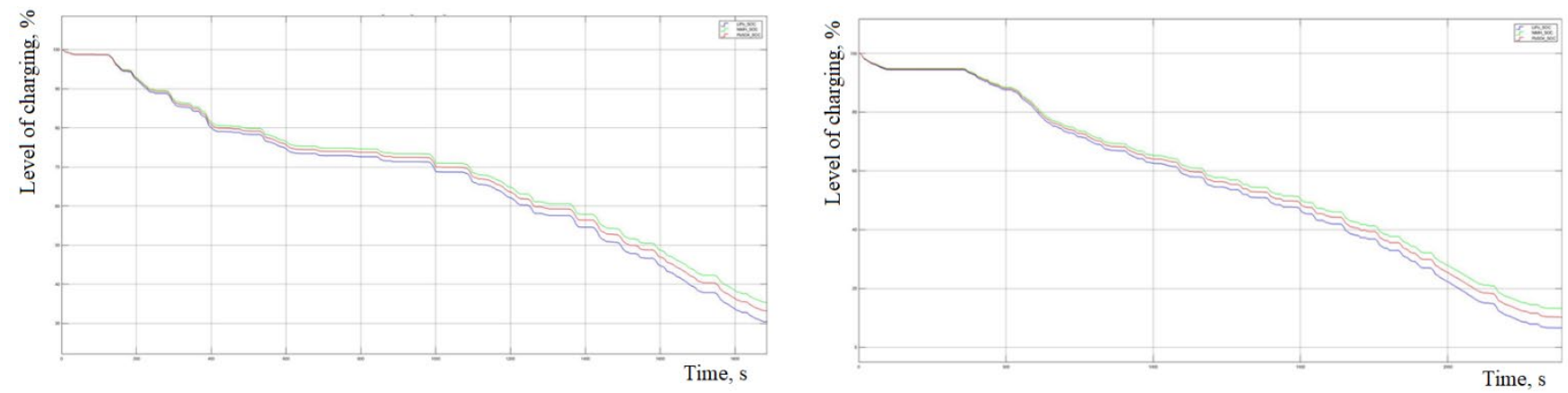

Fig. 8. Discharge levels of different accumulators of routes No. 5 and No. 2. Green - nickel-metal hydride, red - lead acids; blue - lithium-ion.

Figures 7 and 8 demonstrate discharge levels of different accumulators of routes No. 5 and No. 2 during the simulation time.

TABLE I

MODELLING RESULTS

\begin{tabular}{|c|c|c|c|c|}
\hline & $\begin{array}{c}\text { Route } \\
\text { No. 5 } \\
\text { with } \\
\text { regenera- } \\
\text { tion }\end{array}$ & $\begin{array}{c}\text { Route } \\
\text { No. 5 } \\
\text { without } \\
\text { regenera- } \\
\text { tion }\end{array}$ & $\begin{array}{c}\text { Route } \\
\text { No. 2 with } \\
\text { regenera- } \\
\text { tion }\end{array}$ & $\begin{array}{c}\text { Route } \\
\text { No. 2 } \\
\text { without } \\
\text { regenera- } \\
\text { tion }\end{array}$ \\
\hline $\begin{array}{c}\text { Type of } \\
\text { accumulator }\end{array}$ & $\begin{array}{c}\text { Charging } \\
\text { level }\end{array}$ & $\begin{array}{c}\text { Charging } \\
\text { level }\end{array}$ & $\begin{array}{c}\text { Charging } \\
\text { level }\end{array}$ & $\begin{array}{c}\text { Charging } \\
\text { level }\end{array}$ \\
\hline NiMH & $52.88 \%$ & $35.37 \%$ & $30.36 \%$ & $13.23 \%$ \\
\hline $\mathrm{PbSO}_{4}$ & $51.29 \%$ & $33.18 \%$ & $28.00 \%$ & $10.29 \%$ \\
\hline Lithium-ion & $49.26 \%$ & $30.4 \%$ & $25.00 \%$ & $6.55 \%$ \\
\hline
\end{tabular}

The difference in modelling with and without regeneration was $18.16 \%$ for route No. 5 and $17.76 \%$ for route No. 2 . This result correlated with the assumption that an electric vehicle could regenerate the level of charge from $15 \%$ to even $40 \%$ from the consumed energy on a particular route [6].

\section{B. Modelling the Voltage Level for Different Types of Accumulators}

Figure 9 shows the voltages of different types of accumulators during the simulation time.

In accordance with the technical documentation, the level of the rated voltage for Nissan Leaf accumulator is $402.3 \mathrm{~V}$ [7]. Table II summarises the minimum and maximum values of the voltage for different accumulators during the modelling time. The data in the Table II demonstrate that lithium-ion and NiMH accumulators can operate with higher values and provide more effective regeneration than a lead-acid accumulator that has larger voltage drops with an increase in the consumed current.

TABLE II

Voltage Modelling Results

\begin{tabular}{|c|c|c|c|c|}
\hline & \multicolumn{2}{|c|}{ Route No. 5 } & \multicolumn{2}{c|}{ Route No. 2 } \\
\hline $\begin{array}{c}\text { Types of } \\
\text { accumulator }\end{array}$ & $\begin{array}{c}\text { Minimum } \\
\text { value, } \mathbf{V}\end{array}$ & $\begin{array}{c}\text { Maximum } \\
\text { value, V }\end{array}$ & $\begin{array}{c}\text { Minimum } \\
\text { value, V }\end{array}$ & $\begin{array}{c}\text { Maximum } \\
\text { value, } \mathbf{V}\end{array}$ \\
\hline NiMH & 362 & 580 & 362 & 580 \\
\hline $\mathrm{PbSO}_{4}$ & 254 & 790 & 254 & 790 \\
\hline $\mathrm{Li}-$ ion & 368 & 536 & 368 & 536 \\
\hline
\end{tabular}

\section{Influence of the Outside Temperature on Accumulators}

The following results were obtained during the testing of the lithium-ion accumulators. The initial parameters for this type of experiments were the temperature at the accumulator rated operation values, as well as parameters of the accumulator at a lower level of temperature, e.g., voltage and capacity of the accumulator at $0{ }^{\circ} \mathrm{C}$ or $-25^{\circ} \mathrm{C}$.

Three temperatures $\left(+35^{\circ} \mathrm{C} ; 0{ }^{\circ} \mathrm{C} ;-25^{\circ} \mathrm{C}\right)$ were selected for modelling in accordance with the data for 2016 and 2017 from the Geology and Meteorology Centre of Latvia for Jelgava region. Table III presents the modelling results. 

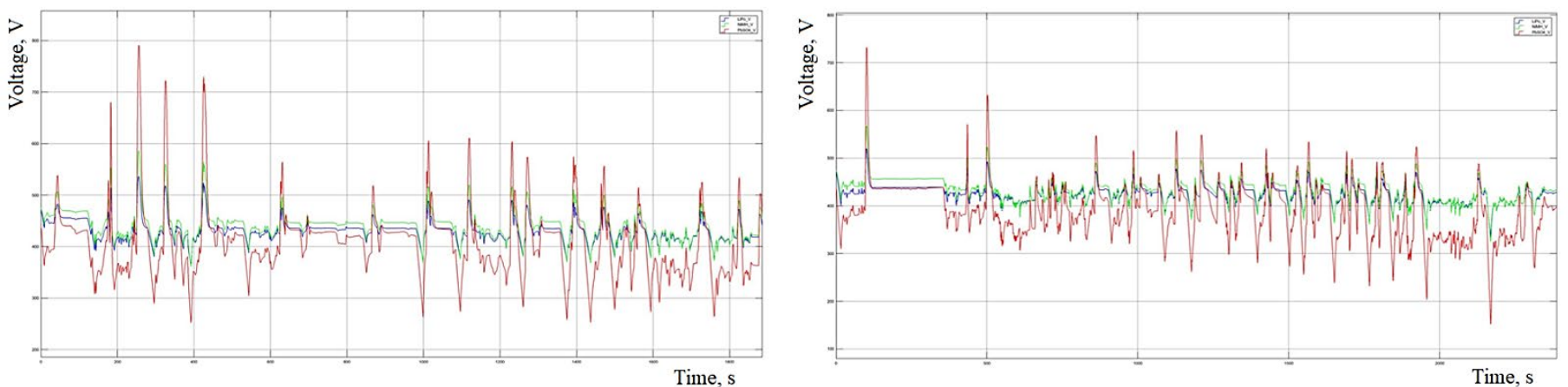

Fig. 9. Voltages of different types of accumulators during the simulation of the same routes correspondently. Green - nickel-metal hydride, red - lead acids; blue - lithium-ion.

The comparison of the obtained results with the previous results presented in Table I states their correspondence at the positive temperatures and can be considered a nominal operation temperature. With a decrease in temperature of the environment, the level of the accumulator charging also rapidly decreases. In this case the calculated results can decline in their accuracy as the ambient temperature is assumed constant and in the model the lithium-ion accumulators are not provided with cooling.

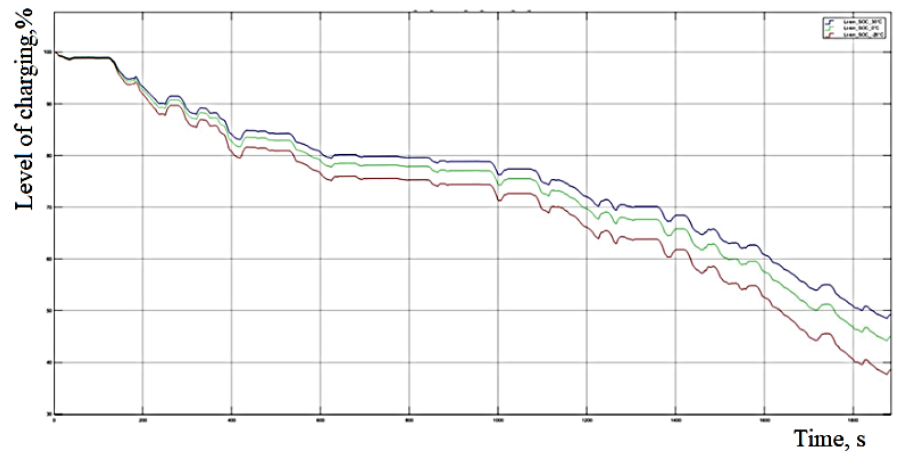

TABLE III

MODELLING RESULTS

\begin{tabular}{|c|c|c|}
\hline & Route No. 5 & Route No. 2 \\
\hline Environmental temperature & Level of charging & Level of charging \\
\hline $0{ }^{\circ} \mathrm{C}$ & $45.00 \%$ & $18.71 \%$ \\
\hline$-25^{\circ} \mathrm{C}$ & $38.60 \%$ & $9.19 \%$ \\
\hline$+35^{\circ} \mathrm{C}$ & $49.26 \%$ & $25.00 \%$ \\
\hline \multicolumn{2}{|c}{} \\
\hline
\end{tabular}

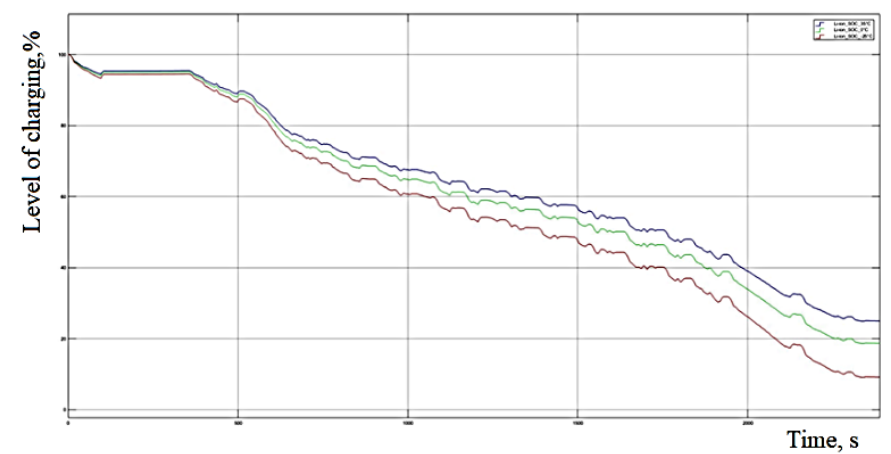

Fig. 10. Voltages of different types of accumulators during the simulation for routes No. 5 and No. 2. Green - at $0{ }^{\circ} \mathrm{C}$; red - at $-25^{\circ} \mathrm{C}$; blue - at $+35^{\circ} \mathrm{C}$.
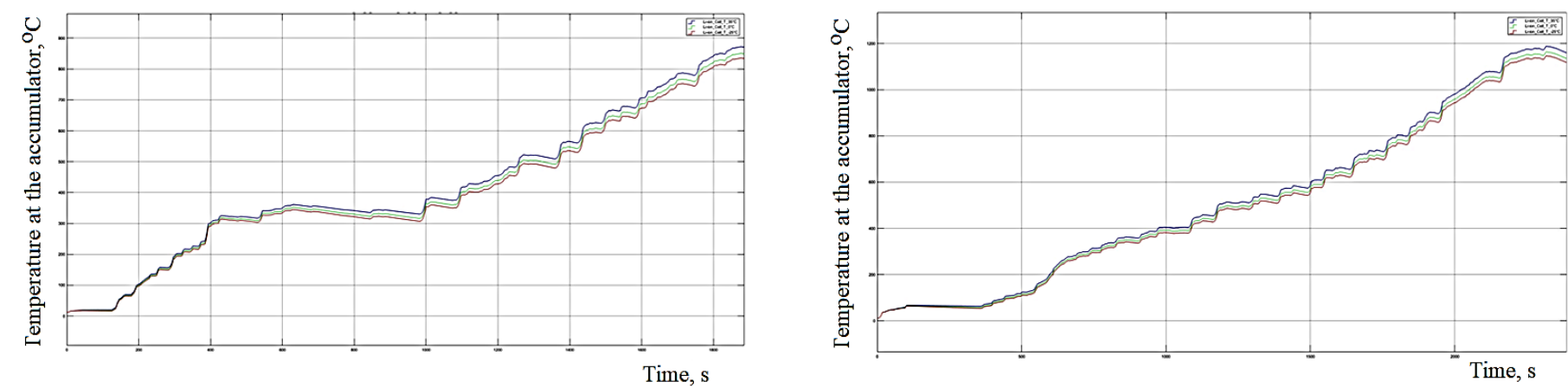

Fig. 11. Temperature of the accumulators for routes No. 5 and No. 2. Green - at $0{ }^{\circ} \mathrm{C}$; red - at $-25^{\circ} \mathrm{C}$; blue - at $+35^{\circ} \mathrm{C}$.

\section{CONCLUSION}

The proposed mathematical model of electric transport is able to calculate the charge level of the battery depending on the speed of the examined routes and simulated different ambient temperatures for lithium-ion batteries. The model can be considered a function given that the calculation of the momentary speed of the route and the length of the road coincide. Therefore, this model can be used to analyse electric transport batteries and their possible operating modes. Model inaccuracies can be characterised by accepting many parameters 
based on literature sources, but within the model these parameters can be changed depending on the available data. There are two dominant types of batteries that have been approved for simulation - lithium-ion and nickel-metal hydride. The use of both types of batteries in the future depends heavily on their development, or the ability to create batteries with higher indicators of energy and energy density at lower cost.

Considering the similarity of simulation results to different chemical types of the batteries, selection should be based on other battery parameters, such as energy density and the required instantaneous power that the battery can provide. Based on the simulation results and the selected battery parameters, it can be concluded that the bus can take the route up to two times for bus route No. 5 (total $26 \mathrm{~km}$ ) and only one stage for bus route No. $2(\sim 20 \mathrm{~km})$, after which the accumulator of the public electric transport will require charging. The choice of battery type and capacity is directly related to the selected bus route. The short travel distance is due to the fact that the selected battery for simulation is from light electric transport. It could be recommended to set up a battery charging station at each end of the bus route, as the bus tends to stay for a while after the end of the route.

\section{ACKNOWLEDGMENT}

This article is based upon the project "Development of Economically Justified Technology of Conversion of the Traditional Diesel City Bus into the Environmentally Friendly Electrobus" that is funded by Activity 1.1.1.1 "Practical Research Aid" of Specific Aid Objective 1.1.1 "To increase the research and innovative capacity of scientific institutions of Latvia and the ability to attract external financing, investing in human resources and infrastructure" of the Operational Program "Growth and Employment", 2017-2020; the project is initiated by JSC Ferrus.

\section{REFERENCES}

[1] X. S. Chen, et al. "An overview of lithium-ion batteries for electric vehicles," 10th International Power \& Energy Conference (IPEC), Ho Chi Minh City, Vietnam. IEEE, pp. 230-235, Dec. 2012. https://doi.org/10.1109/ASSCC.2012.6523269

[2] K. E. Aifantis, S. A. Hackney, \& R. V. Kumar, High Energy Density Lithium Batteries: Materials, Engineering, Applications. Weinheim: Wiley-VCH Verlag GmbH \& Co. KGaA, 2010. https://doi.org/10.1002/9783527630011

[3] T. Reddy, Linden's Handbook of Batteries, 4th Edition. McGraw Hall, 2011.

[4] A. B. Affanni, et al. "Battery choice and management for new-generation electric vehicles," IEEE Transactions on Industrial Electronics, vol. 52 , Issue 5, 1343-1349, 2005. https://doi.org/10.1109/TIE.2005.855664

[5] T. Miller, "Lithium Ion Battery Automotive Applications and Requirements," Proc. $17^{\text {th }}$ Annual Battery Conference on Applications and Advances, Long Beach, CA, USA, IEEE, 2002, pp. 113-118.

[6] A. Moshirvaziri, "Lithium-ion battery modeling for electric vehicles and regenerative cell testing platform". Available: https://pdfs.semanticscholar.org/89c5/c440dc79057ddc7f1d0ea12cf5364 2f4461a.pdf. [Accessed: 27-Mar-2018].

[7] Nissan, "2011 Leaf First Responder's Guide", 2011.p. 9.

[8] C. De Cauwer, J. Van Mierlo, and T. Coosemans, "Energy consumption prediction for electric vehicles based on real-world data", Energies, vol. 8, no. 8, 2015, pp. 8573-8593. https://doi.org/10.3390/en8088573

[9] A. A. Andreev, A. G. Vozmilov, and V. A. Kalmakov, "Simulation of lithium battery operation under severe temperature conditions," Procedia Engineering, 2015, vol. 129, pp. 201-206. https://doi.org/10.1016/j.proeng.2015.12.033
[10] T. A. T. Mohd, M. K. Hassan, and W. A. Aziz, "Mathematical Modeling and Simulation of an Electric Vehicle," J. Mech. Eng. Sci., vol. 8, 2015, pp. 1312-1321. https://doi.org/10.15282/jmes.8.2015.6.0128

[11] O. Tremblay and L. A. Dessaint, "Experimental validation of a battery dynamic model for EV applications", World Electr. Veh. J., vol. 3, no. 2, 2009, pp. 289-298. https://doi.org/10.3390/wevj3020289

[12] L. Model, L. Model, and N. Model, "Implement generic battery model Simulink Implement generic battery model - Simulink", 2010. Available: https://se.mathworks.com/help/physmod/sps/powersys/ref/battery.html. [Accessed: 06-May-2018].

[13] M. Young, The Technical Writer's Handbook. Mill Valley, CA: University Science, 1989.

[14] M. Moshirvaziri, "Ultracapacitor/Battery Hybrid Energy Storage Systems for Electric Vehicles," Master Thesis, 2012.

[15] J. Cherry, "Battery Durability in Electrified Vehicle Applications: A Review of Degradation Mechanisms and Durability Testing," Final Report EP-C-12-014 WA 3-01, FEV, August 7, 2015.

[16] G. Albright, J. Edie, and S. Al-Hallaj, "A Comparison of Lead Acid to Lithium-ion in Stationary Storage Applications," Lead Acid versus Lithium-ion White Paper, AllCell Technologies LLC, 2012. pp. 1-14.

[17] R. Hutchinson, "Temperature Effects on Sealed Lead Acid Batteries and Charging Techniques To Prolong Cycle Life," Technical Report, OSTI.GOV, June 2004. https://doi.org/10.2172/975252

[18] batteryStuff.com, "Battery Basics: A Layman's Guide to Batteries," 2018. [Online]. Available: https://www.batterystuff.com/kb/articles/batteryarticles/battery-basics.html. [Accessed: 27-Mar-2018]

[19] B. Shopping, "Lithium-Ion Batteries for Electric Vehicles," p. 76, 2014

[20]C. Linse and R. Kuhn, Design of high-voltage battery packs for electric vehicles, in Advances in Battery Technologies for Electric Vehicles, Woodhead Publishing Series in Energy, 2015, pp. 245-263. https://doi.org/10.1016/B978-1-78242-377-5.00010-8

[21] D. G. Vutetakis, “Batteries,” Douglas Batter. Co., pp. 217-234, 2001.

[22] ALABC, "Do Hybrid Electric Vehicles Use Lead-Acid Batteries? Yes! Here's why.," 2013.

[23] Festo Didactic, "Battery Fundamentals," Fet Fundamentals Lab Volt Answers Teacher Guide, 2017.

[24]S. Dhameja, Electric Vehicle Batteries, in Electric Vehicle Battery Systems, 2002, pp. 1-21. https://doi.org/10.1016/B978-0750699167/50001-7

[25]E. A. Grunditz, "BEV Powertrain Component Sizing With Respect to Performance, Energy Consumption and Driving Patterns", Chamlers University of Technology, 2014, pp. 3-107.

[26] J. Dirba and K. Ketners, "Elektriskās mašinnas”. Riga: RTU, 2009, p. 34.

Jurijs Fedotovs obtained the Bachelor degree and Master degree from RTU in 2016 and 2018, respectively. He has a large experience in working for FIMA company as an engineer-designer. The area of scientific interest is batteries and their application in electric vehicles.

E-mail: Juris1410@inbox.lv

Inna Bunina, Dr. sc. ing., Assistant Professor. She defended her Doctoral Thesis in 2005 at Riga Technical University (RTU), Latvia. From 2006 to 2012, she worked as a Research Assistant at the Institute of Industrial Electronics and Electrical Engineering of RTU. She had been working as an Engineer at JSC Riga Electric Machine Building Works for about 10 years. Since 2012, she has been an Assistant Professor at the Institute of Industrial Electronics and Electrical Engineering of RTU. The fields of scientific interests are electric machines, control of electric machines and drives, application of mathematical methods in electrical engineering, energy saving. She teaches students and participates in different Latvian and international projects.

She is an author of more than 15 scientific and methodological publications. Address: Āzenes Str. 12/1, Riga, LV-1050, Latvia.

E-mail: inna.bunina@rtu.lv

ORCID iD: https://orcid.org/0000-0002-2605-0298 
Anastasia V. Zhiravetska, Dr. sc. ing., Professor. She defended her Doctoral Thesis in 1999 at Riga Technical University (RTU), Latvia. From 2005 to 2014, she was an Associated Professor. Since 2014, she has been a Professor at the Institute of Industrial Electronics and Electrical Engineering of RTU. The fields of scientific interests are power electronics, electric drives, motion control, adjustable electric drives, automation systems, energy saving and use of terminology in all these areas. She teaches students and participates in different Latvian and international projects. She is a scientific expert of the Latvian Academy of Sciences. In 2014/2015, she developed and successfully implemented a new interdisciplinary study programme "Adaptronics" for the Bachelor professional level at Riga Technical University. She is an author of more than 70 scientific and methodological publications, scientific monographs and textbooks.

Address: Āzenes Str. 12/1, Riga, LV-1050, Latvia.

Phone: +3717089917

E-mail: Anastasija.ziravecka@rtu.lv

ORCID iD: https://orcid.org/0000-0002-0373-7257
Svetlava Andrianova, Dr. sc. ing., Assistant Professor. She defended her Doctoral Thesis in 2005 at Riga Technical University (RTU), Latvia. From 2006 to 2019, she was an Assistant Professor at the Institute of Power Engineering. Since 2019, she has been an Assistant Professor at the Institute of Industrial Electronics and Electrical Engineering of RTU. The fields of scientific interests are electric machines, control of electric machines and drives, application of mathematical methods in electrical engineering, energy saving. She teaches students and participates in different Latvian and international projects. She is an author of more than 20 scientific and methodological publications. Address: Āzenes Str. 12/1, Riga, LV-1050, Latvia. E-mail: Svetlana.andrianova@rtu.lv 